\title{
SECURITY EDUCATION IN AFRICA: PATTERNS AND PROSPECTS
}

\author{
David Last, David Emelifeonwu, Louis Osemwegie \\ Royal Military College of Canada
}

\begin{abstract}
This article is part of a larger study exploring global patterns of security education, in order to enhance the collaborative pursuit of security by the majority of the world's countries. We draw on interviews at multinational training events, site visits and open sources. Here we describe general patterns of police, gendarme and military education in Africa, with particular attention to university-like institutions. This leads us to focus on mid-career military staff colleges as the most likely venues for building communities of educated professionals to enhance security. We identify states in each region with the greatest potential to play a leading role in the development of knowledge addressing new security challenges. South Africa, Nigeria and Kenya have obvious educational potential. Good governance and national policies are more important than size and wealth, and this suggests that smaller states like Senegal and Botswana could make important contributions. Mechanisms contributing to regional security communities include the African Peace and Security Architecture, career incentives, innovation, and regional training centres. Understanding the patterns of security education lays the groundwork to understand innovation, diffusion and the influence of the content of security of education.
\end{abstract}

\section{Introduction}

Africa's continuing insecurities are an indictment of security professionals. We really do not understand much about enhancing human security, national security and international security, even when we know how to plan brigade and division operations. Conventional operations seem increasingly disconnected from emerging threats like survival migration, climate change and radicalisation that

Scientia Militaria, South African Journal of Military Studies, Vol 43, No. 1, 2015, pp. 17 - 44. doi : $10.5787 / 43-1-1108$ disregard borders. Dambisa Moyo makes the case in her book, Dead aid, that billions in development aid have done little good and much harm. ${ }^{1}$ The same case might be made for military spending and perhaps foreign security 
education. Graduates of Sandhurst and Leavenworth, after all, have sometimes become predatory military heads of state. ${ }^{2}$ However, Africa may be moving beyond these problems towards focused efforts to prepare leaders who will improve security. If knowledge of development and conflict has been isolated in the past, ${ }^{3}$ where might it be understood and taught effectively in the future? What are the patterns of security education in Africa, and how can these be used to support the development of regional security communities that meet national and human needs? By examining broad patterns of security education in sub-Saharan Africa, we conclude that focusing cooperative efforts on mid-career officer education will probably reap the largest rewards for security in the broadest sense. However, this is not a prescription for foreign education; it is a call for African institutions to continue to lead the way to their own solutions.

Our work focuses on the preparation of officers and leaders in the command structure of security forces, because this is the group from which professional expertise is drawn to meet security challenges. These are the leaders who construct ideas about what must be secured, and against which threats. ${ }^{4}$ We consider all uniformed security forces - police, paramilitary or gendarme, military and ancillary services. In the majority of the world's states, ${ }^{5}$ the responsibilities of the uniformed security forces overlap and converge. This becomes more pronounced as we focus on emerging threats and small countries. We can describe the broad patterns of professional preparation for leaders at entry level, at mid-career and for senior officers, but we cannot yet describe detailed course content or the effect of such content in individual countries.

Professional preparation inevitably includes socialisation, training and education in varying combinations. Socialisation is the inculcation of values, attitudes and beliefs. ${ }^{6}$ Training is the transfer of accepted knowledge, skills and competencies. ${ }^{7}$ We are mostly interested in education, because it is the cultivation of understanding, of habits of mind including critical thinking, and of problem-solving capacity. Socialisation, education and training always proceed together. An act as simple as teaching small arms safety to recruits includes all three elements, where the repetitive drill is training, the habit of respect for the instructor is socialisation, and the critical understanding of the danger of weapons entails education.

Military sociologist Giuseppe Caforio examined European military officer education through the lens of the secondary socialisation that occurs through selection and education of officers. ${ }^{8}$ We start by asking whether an institution has the capacity to provide higher education as the Bologna process defines it: is a police academy or staff college 'university-like'? The Bologna process seeks to harmonise higher education standards, including three- or four-year first degrees, 
followed by one- or two-year master's degrees. Quality assurance focuses on institutional governance, external evaluation and accreditation of institutions, expert instruction demonstrated by research and publications, and freedom of enquiry. We used the Bologna criteria to compare university-like institutions responsible for higher education of security leaders. ${ }^{9}$

The information about African security institutions responsible for higher education has been collected along several tracks as part of a continuing global comparative study of security education. Open source data collection gives us an incomplete glimpse of the curriculum and its context for institutions with an international profile. Direct approaches yielded slim results. ${ }^{10}$ The most fruitful sources of information have been participants in multinational short courses held in Gaborone in December 2011: 46 interviews were conducted with officers from 18 countries and 16 institutions. More than 60 additional interviews were conducted at subsequent training events in August 2012 (Rio de Janeiro) and January 2014 (Sentul and Jakarta, Indonesia). ${ }^{11}$ These were followed up with mail and telephone communications, collection of texts and secondary sources. A web site was established in November 2013 to expand the collaborative sharing of curricular materials. ${ }^{12}$ Both the web site and individual interviews are based on the principle that individual contributors will not be identified, ensuring $\mathrm{k}$-anonymity once enough participants are secured from any given country or institution cited. ${ }^{13}$

We are particularly interested in the emergence of regional security communities. These consist of states that cooperate to solve common threats - states that are unlikely to use force against each other. The Copenhagen school developed the theory of the international system as a social construction. ${ }^{14}$ This is important for the evolution of security, because social constructions evolve, playing a role in accelerating or reducing violence, within and between states. The long-term decline in violence is enhanced by the state's monopoly of force and by changing social conventions, which reduce incentives for interpersonal violence. ${ }^{15}$ State forces can inflict violence on their own populations, ${ }^{16}$ but can also help reduce deaths from war and organised violence through peacekeeping and humanitarian missions. ${ }^{17}$

Education (along with socialisation and training) shapes the security leaders who construct these alternatives within and between states. Military and police leaders should understand the political, social and economic causes and correlates of violence, if they are to manage it. We believe that military institutions with the characteristics of universities play an important role in this process, because they can generate, preserve and transmit new knowledge for professionals. 


\section{Patterns of security education}

We can describe how security education is delivered, based on secondary sources and institutional descriptions, augmented by interviews with people who know the institutions in question. Conceptually, police, gendarme and military organisations can be seen as a continuum of forces providing for security. In practice, they are institutionally distinct and often compete for resources.

There are general patterns of security education evident around the world. These sometimes reflect colonial influences, so we sometimes read of British, French, American or Russian models, or a Latin-American pattern. ${ }^{18}$ However, we can also find a great variety in the adoption and evolution of indigenous models, particularly in smaller countries. Entry-level institutions tend to focus on socialisation and training rather than on education. Mid-career institutions broaden the education and competence of security leaders, and senior officer courses tend to focus on strategic and political implications. ${ }^{19}$ This progression distinguishes military and police from professions like medicine, engineering and law. Other professions begin with a common body of knowledge, and progress towards greater specialisation. Military and police professionals begin with specialisation, and progress towards a more general understanding of the profession: leaders are first inducted into the specialised tribes of urban police, border police, infantry, artillery, navy or air force, and only begin to integrate those specialties as they progress through command and staff colleges to senior ranks.

University education is important, because it implies sustained study (three or four years of mature learning) to develop critical thinking and analytical competence within an academic discipline. It is in the upper years of a first degree that students demonstrate the capacity for self-directed learning, and in a second degree, they progress to the generation of new knowledge based on mastery of sources and methods. ${ }^{20}$ Most second degrees imply greater specialisation within a discipline, but professional degrees - like a Master of Business Administration (MBA) or the Master of Defence Studies (MDS) at the Canadian Forces College build a capacity for teamwork and for combination of specialised knowledge.

Based on our global data set (193 countries and about 600 institutions), about 20 per cent of military institutions at entry, mid-career or senior officer level offer degrees or approach being university-like according to the Bologna criteria. ${ }^{21}$ We have not attempted to catalogue the many specialised training centres, bases or posts offering technical qualifications to junior or non-commissioned officers. This compares to about 13 per cent of gendarme establishments (mostly in the former Republics of the Soviet Union) and just 7 per cent of police colleges. ${ }^{22}$ This ratio 
does not indicate the number of officers with degrees, because many receive education at civilian universities. Nevertheless, it is indicative of the number of institutions with the capacity to generate knowledge within each of the security professions at a global level. In the five regions Buzan and Waever identify in Africa, ${ }^{23}$ we found no police or gendarme institutions that approximated universities, and only six military institutions, or about 14 per cent of the total.

Military and police institutions of higher learning usually mix uniformed and civilian faculty members. Many of the uniformed faculty are rotated at short intervals, spending only two or three years in teaching positions before moving on to command or staff jobs. Their qualification to teach rests on their recent experience, rather than higher education, research or publications. Even civilian faculty, frequently retired officers, may be limited to short contracts, in contrast to civilian universities where they might hold tenure. The result is that few faculty members have both professional expertise and the benefit of original research and publication in their field. The situation contrasts with medicine, law and engineering schools, in which faculty are expected to publish and practice. ${ }^{24}$ This is true in most security education institutions, although there is evidence that it may be changing as more academies and staff colleges seek university accreditation. ${ }^{25}$

Having noted these general patterns, we can now discuss the patterns specific to police, gendarme and military education in Africa south of the Sahara.

Police are typically recruited after secondary education, although some countries require post-secondary degrees or certificates for aspirants to police leadership. ${ }^{26}$ At entry level, there are fewer police than military specialties, so police education tends to be more consistent, with a foundation of law, administration and criminology (or sociology) in most police colleges. Police higher education, distinct from training, is usually at civilian universities, while training and socialisation after induction are often divided into a series of short courses. ${ }^{27}$ Police staff colleges are less universal than military staff colleges. However, even quite small countries have their own police training centres for the rank and file. ${ }^{28}$

Formed police units for crowd control or border security may be part of the same organisation as regular urban or national police forces. This is the norm for former British colonies. Francophone African countries often have gendarmeries paramilitary organisations with additional responsibilities for territorial control, route security and support to national armed forces. ${ }^{29}$

Gendarmes normally have their own schools at entry level, but their leaders typically take mid-career education in police or military staff colleges, and in the École nationale à vocation régionale (regionally based vocational school) sponsored 
by France in Senegal. ${ }^{30}$ Nigeria and Senegal have emerged as major providers of formed police units, but there remain critical skills shortages and basic deficiencies in planning to maintain order and rule of law. ${ }^{31}$

Military leaders are usually recruited and developed separately from the rank and file. Military education may involve an initial degree (based on the West Point model) or some classroom learning in a short course (based on the Sandhurst or St Cyr models). ${ }^{32}$ A growing number of countries require or encourage university degrees for military officers. Officers are typically educated in successive stages, each involving socialisation, training and education. Socialisation and training typically predominate in the first stage, leading to a junior officer's commission and sometimes a degree shortly after entry. Mid-career staff colleges concentrate on technical competence in command and staff positions. Many countries divide this between junior staff college for captains and senior staff college for majors. Senior officers (colonels and generals) may attend national defence colleges to prepare them for strategic leadership, often with civilian and foreign participants. ${ }^{33}$

Entry-level programmes for officers in Africa concentrate on training and socialisation with only three exceptions - Nigeria, South Africa and Kenya. Other officer candidate schools require classroom work that reflects critical thinking and development of judgement, but falls short of the Bologna criteria. Cadets at Botswana's Paje Officer Academy, for example, are assigned reading assignments and they prepare book reviews. ${ }^{34}$ As with most police and gendarme education, the course duration of less than 12 months is too short to meet the Bologna criteria, and instructors are not scholars. Junior staff colleges aimed at captains likewise train for competence in core military skills, and courses generally range from three to six months in length. ${ }^{35}$

The Nigerian Defence Academy in Kaduna, the South African Military Academy in Saldanha Bay, and the Kenyan Military Academy in Nakuru are the exceptions. They offer undergraduate degrees and commissions to junior officers. The Nigerian Defence Academy has military and civilian instructors. Qualified civilian instructors teach academic courses in three faculties: arts and social sciences, sciences, and engineering. Uniformed instructors teach military courses, some of which receive academic credit. For example, aspiring air force officer cadets may earn credit towards a science degree for a course on the physics of flight, but those in a history programme will learn the essentials without academic credit. In 2004, the Nigerian Defence Academy added a postgraduate school, expanding it in 2009 as an integrated postgraduate campus. The Nigerian National Universities Commission accredited its programmes in $2012 .^{36}$ 
While Nigeria's Defence Academy is autonomous, South Africa's Saldanha Bay and Kenya's Military Academy have partnered with civilian universities to provide the accredited content for undergraduate degrees. After experimenting with the West Point model, the South African Military Academy was established on the tri-service model of the Indian National Defence Academy. The partnership with the University of Stellenbosch dates from 1956, with the Academy achieving faculty status within the university in $1961 .^{37}$ The Kenyan Military Academy (KMA) was established in 2008, and initially offered short courses for officers based on the Sandhurst model. ${ }^{38}$ Since 2010, the KMA has offered a 36-month programme for general service officers, culminating in a commission and a bachelor of science in military studies from Kenyatta University. The new connection with the Kenyatta University Institute of Peace and Security Studies reinforces other Kenyatta programmes in Security Management and Police Studies, and in Forensic Science and Criminal Investigation. ${ }^{39}$

Although only three entry-level military academies offer degree programmes, the move towards more rigorous education in mid-career staff courses is raising awareness of and demand for university education amongst officers. To meet the Bologna criteria, the coveted master's qualification at mid-career requires a prior undergraduate degree. If it is to be achieved within a 12-month staff college course, then four-year degrees like the ones offered to Nigerian and South African cadets are preferable to the three-year degree offered in Kenya. If graduates of military academies find themselves at a disadvantage at mid-career, there will be pressure to upgrade the entry-level qualification. ${ }^{40}$

Outside these three exceptional entry-level institutions, command and staff colleges for majors with 10 to 15 years of service are the first place we find curricula routinely requiring critical thought, reading, research and problem solving beyond tactical military situations. These courses are typically either six or ten months long. Most staff colleges have cohorts of about 30 to 50 officers. Students attend plenary lectures, followed by discussions or group work in syndicates of 8 to 15 officers. Syndicates are directed by a lieutenant colonel or colonel who is a graduate of a staff college. Officers who are expected to progress in rank compete for positions at command and staff colleges. The most successful achieve promotion and continue for another 15 to 25 years of service. Because officers attending mid-career staff colleges form the backbone of professional military leadership, and frequently interact with the armed forces of other states in the region, this is the most important group in which to inculcate an understanding of security.

Staff college curricula provide a common language and planning framework to approach security problems. ${ }^{41}$ Staff colleges typically include three or four major 
blocks of study. The largest block is usually devoted to conventional military operations at formation level (brigade and division) with a focus on the operational planning process. This prepares officers to manage logistics, communications, combat power and the challenges of command, control and intelligence in scenarios with an enemy. The basic skills are applicable to any scenario, and shorter blocks typically address peacekeeping, aid to civilian authorities (e.g. disaster response) and operations other than war (including internal security, anti-poaching operations and counter-insurgency in some countries). ${ }^{42}$ From discussions with instructors and graduates of African staff colleges, there appears to be a significant amount of local innovation in modules on peacekeeping operations, operations other than war, and support to government authorities. This builds on the career experiences of senior officers in the directing staff. ${ }^{43}$

Staff college libraries are potentially important as repositories of knowledge. A typical staff college library may have five to ten thousand volumes on general subjects, with a preponderance of material on international relations, strategic studies and conflict. Even when staff colleges are associated with civilian universities that have large libraries (as in Kenya, Botswana and Namibia), students are pressed for time, and do not spend much time away from the staff college campus. Electronic solutions are imperfect because of download speeds and device limitations. In most countries, reading lists and acquisitions are influenced by the United Kingdom and the United States, and by France in la Francophonie. EBSCOhost, MERLN and Columbia International Affairs Online (CIAO) are electronic resources common to many military institutional libraries, although their use varies widely.

Unpublished studies, papers and doctrine manuals (also called 'grey literature') are not widely catalogued. ${ }^{44}$ Archival and primary sources from operations are not routinely collected or retained in most African institutions. Some participating officers lamented their own institutional amnesia, but few saw it as a major issue, because they tended to focus on knowledge acquired abroad. As staff colleges begin to require students to produce major research papers, and as they seek university accreditation for staff college courses, there is a nascent move to retain student papers. This is the beginning of a new body of knowledge developed by indigenous professionals. Grey literature is increasingly important in professional education in other professions like medicine. ${ }^{45}$

Thought processes inculcated in mid-career officers are remarkably consistent across national boundaries, drawing on American and NATO doctrine for military operations. India, Pakistan and even China teach in English and use recognisable NATO models and vocabulary in their command and staff courses 
open to African students. French influence presents some barriers to interoperability, according to francophone officers interviewed. These barriers arise from different terminology and staff procedures. Several countries relying on French materials have begun to diversify their sources to improve graduates' capacity to work with regional forces using NATO standards. Officers from Mali and Benin, for example, cited the advantage of the Indian Staff College, because this makes it easier to work with UN staffs. ${ }^{46}$

A small number of senior officers go on to some form of year-long national defence college or senior officer course for generals and admirals. Each year, one or two officers go overseas to traditional providers - the United Kingdom, France and the United States. The most numerous opportunities for senior officers to attend long courses in English are offered by China. These include brigade commanders' courses, air operations courses, and national war college courses. ${ }^{47}$ Tanzania, Namibia, Zimbabwe, Uganda, Ethiopia, Ghana (and perhaps other countries) periodically offer general officer seminars or short courses for senior officers. ${ }^{48}$ Sometimes these have a specific focus, such as law of war or peacekeeping operations, and they are often sponsored or supported by foreign governments or international organisations. Only three countries in Africa provide their own national defence college courses: Nigeria, Kenya and South Africa. These courses are well established, and attract participants and instructors from other countries.

Senior officer curricula from Nigeria and South Africa demonstrate innovative thinking. In Nigeria, the curriculum includes discussion and original research on economics, agricultural and industrial policy, demographics and international law. Senior police, diplomats and other government officials often participate in this final stage of senior leader development. ${ }^{49}$

\section{Prospects for security education}

Given the general patterns of security education in Africa, what are the prospects for improving regional security communities through professional education? We need to consider which services and what stage of career education are likely to have an effect on thinking about regional security.

Police and gendarme mandates are most directly concerned with community safety and the preservation of order affecting human security, but are less involved in national and regional security questions. They are less likely to be engaged internationally, and often have only short courses at mid-career. Our attention is drawn to military institutions because military officers are most likely to be educated in their own schools with lengthy mid-career courses, and more likely to have 
international connections through their profession. Police and gendarme officers are more likely to be locally focused, and military educational institutions are more likely to have or to aspire to university credentials. ${ }^{50}$

Within the spectrum of military education, senior officer courses might seem the logical place to influence security thinking, because we find influential senior officers and civilian leaders in these courses. However, this potential may be illusory. The most influential officers may be too busy to take time off for senior courses. If the programme of studies is longer than a few months or held in a foreign country, senior officers may suffer career disadvantage by attending. ${ }^{51}$ Many of the participants will be close to retirement, and may hold only one or two more posts in their careers. The main value of networking may be post-retirement advantage. ${ }^{52}$

The constraints of police, gendarmes, entry-level and senior military education all direct us towards mid-career military staff colleges as the most useful venues for building communities of educated professionals capable of enhancing security across national boundaries. Knowing the institutions that are most likely to be central to this process, we can now focus on identifying the countries within which these institutions might have the most potential.

Patterns of police, gendarme and military education in Africa, influenced by colonial experiences, bear strong resemblances to other regions. However, Africa as a whole is comparatively under-serviced by education and training institutions. Only five out of 39 military institutions and none of the 30 police institutions identified in sub-Saharan Africa offer university degrees or have established research programmes. ${ }^{53}$ Large, wealthy countries (measured by population and GDP) have sufficient educational institutions and high budgets for security. ${ }^{54}$

In addition to size and wealth, we can use citable documents as a proxy for universities and other intellectual infrastructure. ${ }^{55}$ Note that these are citable documents in all fields, and they are being used only to indicate potential for generating knowledge in a variety of different academic fields related to security. ${ }^{56}$ Beyond size, wealth and citable documents, we are looking for indicators that a state could play a leading role in the development of new security knowledge within a region. We used seven questions to assess institutional importance in security education, summarised in Table 1, in the lettered columns:

A. Is a bachelor's degree offered or required at entry level? This demonstrates the requirement for and appreciation of critical thinking in junior officers.

B. Is a master's degree offered at mid-career level? This indicates a requirement for professional officers to research and write. 
C. Is senior officer education conducted in the country? Tertiary professional education often attracts civilian and international participants.

D. Is the country a regular participant in staff college networks (for example, the African Conference of Commandants)? This is an indicator of international engagement (autistic states do not participate).

E. Are one or more regional centres located in the capital? (For example, the African Peace and Security Architecture [APSA] peace support training institutions). This is a two-way gate for international engagement.

F. Are there research centres associated with security education? This indicates production of indigenous security knowledge.

G. Does the country export instructors' or officers' curricula to other countries? This is another indicator of international engagement.

In the table, $\mathrm{Y}$ indicates yes, and $\mathrm{P}$ indicates potential or possible (i.e. there is some evidence that the condition has been met, or is in progress). The countries most likely to be perceived as regional hubs appear in bold.

An additional three factors were considered because of their capacity to diminish a state's institutional potential (the last three columns in the table):

$X$. If the country is internally unstable or a pariah within the region, then it will have limited influence with its neighbours.

Y. If the country is in conflict with neighbours in the same region, then it will be difficult for it to share educational influences.

Z. If the country is undemocratic or corrupt according to international indicators (we have used Freedom House 2011, P for partly free), then we surmise that it will have less influence.

Using all the indicators in the table, South Africa, Nigeria and Kenya stand out as the obvious hubs both for the continent and within three of the four APSA regions, with Cameroon a dubious hub for the fourth. The seven questions and the three constraints line up fairly consistently with the largest and wealthiest states in each region.

The number of citable documents $(\operatorname{cit}(\mathrm{k}))$ produced in a country is an important indicator. Peer-reviewed articles emerge from universities, laboratories and libraries connected to the larger world of scholarship. The figure used in the table for citable documents is the total reported for 1996 to 2012, and the ability to produce a stream of citable documents over a prolonged period demonstrates capacity to generate useful knowledge, whether or not this is harnessed to support security. Whether or not military and police academies and staff colleges are 


\begin{tabular}{|c|c|c|c|c|c|c|c|c|c|c|c|c|c|}
\hline State & $\begin{array}{l}\text { Pop } \\
\text { (M) }\end{array}$ & $\begin{array}{l}\text { GDP } \\
(\$ B)\end{array}$ & $\begin{array}{l}\mathrm{Cit}(\mathrm{k} \\
\mathrm{P}\end{array}$ & A & B & $\mathrm{C}$ & D & E & $\mathrm{F}$ & G & $\mathrm{X}$ & $\mathrm{Y}$ & $\mathrm{Z}$ \\
\hline & & & & & & & & & & \multicolumn{4}{|c|}{ EAST (EASBRICOM) } \\
\hline Burundi & 6.7 & .7 & .2 & & & & $\mathrm{Y}$ & & & & & & $\mathrm{P}$ \\
\hline Djibouti & .7 & .6 & .1 & & & & & $\mathrm{Y}$ & & & & & $\mathrm{X}$ \\
\hline Eritrea & 3.7 & .6 & .4 & & & & & & & & & $\mathrm{X}$ & $\mathrm{X}$ \\
\hline Ethiopia & 65.8 & 8.2 & 7.8 & & & $\mathrm{Y}$ & & $\mathrm{Y}$ & & & & $\mathrm{X}$ & $\mathrm{X}$ \\
\hline Kenya & 31.3 & 12.6 & 16 & & $\mathbf{Y}$ & $\mathbf{Y}$ & $\mathbf{Y}$ & $\mathbf{Y}$ & $\mathbf{Y}$ & $\mathbf{Y}$ & & $\mathbf{X}$ & $\mathbf{P}$ \\
\hline Rwanda & 8.2 & 1.7 & .8 & & & & & $\mathrm{P}$ & & & & $\mathrm{X}$ & $\mathrm{X}$ \\
\hline Somalia & 7.1 & $* *$ & 0 & & & & & & & & $X$ & $\mathrm{X}$ & $\mathrm{X}$ \\
\hline $\begin{array}{l}\text { Sudan } \\
\end{array}$ & 33.3 & 12.4 & 3.8 & & & & & & & & $\mathrm{X}$ & $\mathrm{X}$ & $\mathrm{X}$ \\
\hline Uganda & 24.7 & 5.9 & 7 & & $\mathbf{P}$ & & $\mathbf{Y}$ & & & & & $\mathbf{X}$ & $\mathbf{P}$ \\
\hline & & & & & & & & & & & TR & ECC & \\
\hline $\begin{array}{ll}\text { Angola } & \text { (also } \\
\text { SADC) } & \\
\end{array}$ & 13.9 & 9.1 & .4 & & & & & & & & & & $\mathrm{X}$ \\
\hline Cameroon & 15.9 & 10.1 & 7.3 & & & $\mathbf{P}$ & & $\mathbf{P}$ & & & & & $\mathbf{X}$ \\
\hline $\begin{array}{l}\text { Central } \\
\text { African } \\
\text { Republic } \\
\text { (CAR) }\end{array}$ & 3.9 & 1 & .3 & & & & & & & & & & $\mathrm{P}$ \\
\hline Chad & 8.5 & 1.4 & .3 & & & & & & & & $X$ & $\mathrm{X}$ & $\mathrm{X}$ \\
\hline $\begin{array}{l}\text { Congo- } \\
\text { Brazzaville }\end{array}$ & 3.2 & 3.2 & 1.9 & & & & & & & & & & $\mathrm{X}$ \\
\hline $\begin{array}{l}\text { Democratic } \\
\text { Republic of }\end{array}$ & 50.7 & 4.3 & .3 & & & & & & & & $\mathrm{X}$ & $\mathrm{X}$ & $\mathrm{X}$ \\
\hline
\end{tabular}




\begin{tabular}{|c|c|c|c|c|c|c|c|c|c|c|c|c|c|}
\hline State & $\begin{array}{l}\text { Pop } \\
(\mathrm{M})\end{array}$ & $\begin{array}{l}\text { GDP } \\
(\$ B)\end{array}$ & Cit $(\mathrm{k}$ & A & B & $\mathrm{C}$ & $\mathrm{D}$ & $\mathrm{E}$ & $\mathrm{F}$ & G & $\mathrm{X}$ & $\mathrm{Y}$ & $\mathrm{Z}$ \\
\hline \multicolumn{14}{|l|}{$\begin{array}{l}\text { the Congo } \\
\text { (DRC) }\end{array}$} \\
\hline $\begin{array}{l}\text { Equatorial } \\
\text { Guinea }\end{array}$ & .4 & 1.3 & .4 & & & & & & & & $\mathrm{X}$ & & $\mathrm{X}$ \\
\hline Gabon & 1.2 & 5.1 & 1.4 & & & & & & & & & & $\mathrm{X}$ \\
\hline $\begin{array}{l}\text { Sao Tome } \\
\text { Principe }\end{array}$ & .1 & $* *$ & 0 & & & & & & & & & & \\
\hline \multicolumn{14}{|c|}{ WEST (ECOWAS) } \\
\hline Benin & 7.2 & 2.3 & 2.5 & & & & & & & & & & \\
\hline Burkina Faso & 11.9 & 2.6 & 3.3 & & & & & & & & & & $\mathrm{P}$ \\
\hline Cape Verde & .5 & .5 & 0 & & & & & & & & & & \\
\hline Côte d'Ivoire & 17 & 10.4 & 3.6 & & & & & & & & $\mathrm{X}$ & $\mathrm{X}$ & $\mathrm{X}$ \\
\hline Gambia & 1.4 & .4 & 1.4 & & & & & & & & & & $\mathrm{P}$ \\
\hline Ghana & 20.1 & 5 & 6.6 & & & & $\mathbf{Y}$ & $\mathbf{Y}$ & $\mathbf{Y}$ & $\mathbf{P}$ & & & \\
\hline $\begin{array}{l}\text { Guinea } \\
\text { Bissau }\end{array}$ & 1.4 & .2 & .3 & & & & & & & & & & $\mathrm{P}$ \\
\hline Liberia & 3.1 & .6 & .1 & & & & & & & & & & $\mathrm{P}$ \\
\hline Mali & 10 & 2.4 & 1.7 & & & & & & & & & & \\
\hline Niger & 11.1 & 1.8 & 1.2 & & & & & & & & & & $\mathrm{P}$ \\
\hline Nigeria & 124 & 46 & 40 & $\mathbf{Y}$ & $\mathbf{Y}$ & $\mathbf{Y}$ & $\mathbf{Y}$ & $\mathbf{Y}$ & $\mathbf{Y}$ & $\mathbf{Y}$ & & & $\mathbf{P}$ \\
\hline Senegal & 10.3 & 4.7 & 4.8 & & & & $\mathbf{Y}$ & $\mathbf{Y}$ & $\mathbf{Y}$ & $\mathbf{Y}$ & & & $\mathbf{P}$ \\
\hline Sierra Leone & 4.5 & 0.6 & .3 & & & & $\mathbf{Y}$ & & & & & & $\mathrm{P}$ \\
\hline Togo & 5.4 & 1.3 & .9 & & & & & & & & & & $\mathrm{P}$ \\
\hline & & & & & & & & & & & TH & & \\
\hline Angola (also & 13.9 & 9.1 & .4 & & & & & & & & & & $X$ \\
\hline
\end{tabular}




\begin{tabular}{|c|c|c|c|c|c|c|c|c|c|c|c|c|c|}
\hline State & $\begin{array}{l}\text { Pop } \\
\text { (M) }\end{array}$ & $\begin{array}{l}\text { GDP } \\
(\$ B)\end{array}$ & $\begin{array}{l}\operatorname{Cit}(\mathrm{k} \\
)\end{array}$ & A & B & $\mathrm{C}$ & $\mathrm{D}$ & $\mathrm{E}$ & $\mathrm{F}$ & G & $\mathrm{X}$ & $\mathrm{Y}$ & $\mathrm{Z}$ \\
\hline \multicolumn{14}{|l|}{ ECCAS) } \\
\hline Botswana & 1.7 & 6.2 & 3.3 & $\mathrm{Y}^{57}$ & $\mathrm{Y}$ & & $\mathrm{Y}$ & $\mathrm{Y}$ & $\mathrm{P}$ & $\mathrm{Y}$ & & & \\
\hline Lesotho & 1.9 & .9 & .3 & & & & & & & & & & $\mathrm{P}$ \\
\hline Madagascar & 16.2 & 3.9 & 2.2 & & & & & & & & & & $\mathrm{P}$ \\
\hline Malawi & 11.6 & 1.7 & 3.2 & & & & & & & & & & $\mathrm{P}$ \\
\hline Mauritius & 1.2 & 4.5 & 1.4 & & & & & & & & & & \\
\hline Mozambique & 18.2 & 4.2 & 1.5 & & & & & & & & & & $\mathrm{P}$ \\
\hline Namibia & 1.9 & 3.4 & 1.4 & & & & & & & & & & \\
\hline $\begin{array}{l}\text { Republic of } \\
\text { South Africa } \\
\text { (RSA) }\end{array}$ & 44 & 132.9 & 118 & & $\mathbf{Y}$ & $\mathbf{Y}$ & $\mathbf{Y}$ & $\mathbf{Y}$ & $\mathbf{Y}$ & & $\mathbf{P}$ & & \\
\hline Swaziland & 1 & 1.4 & .7 & & & & & & & & & & $\mathrm{X}$ \\
\hline Tanzania & 33.8 & 9.1 & 7.7 & & $\mathbf{Y}$ & $\mathbf{Y}$ & $\mathbf{Y}$ & $\mathbf{Y}$ & $\mathbf{Y}$ & $\mathbf{Y}$ & & & $\mathbf{P}$ \\
\hline Zambia & 10.5 & 3.2 & 2.5 & & & & $\mathbf{Y}$ & & & & & & $\mathrm{P}$ \\
\hline Zimbabwe & 12.7 & 7.4 & 5 & & $\mathrm{Y}$ & $\mathrm{P}$ & $\mathbf{Y}$ & $Y$ & $Y$ & & & & $\mathrm{X}$ \\
\hline
\end{tabular}

Table 1: Most active states in regional security education ${ }^{58}$ 
producing peer-reviewed publications, their faculty and students will have more access to emerging knowledge in countries with better universities, libraries and laboratories.

SCImago also reports annual figures from 1996-2012, and these can be used to indicate trends at continental and regional level. All four hubs show some growth in citable documents, with South Africa and Nigeria strongest. The second tier within each region is also instructive. In the Economic Community of West African States (ECOWAS), Nigeria is followed at some distance by Ghana and Senegal, both showing modest growth in citable documents since 1996. Nigeria dropped in 2012 but is still well ahead of Ghana. The Southern African Development Community (SADC) shows little competition, with Tanzania, Botswana and Zimbabwe (all well behind South Africa) showing low growth. The Eastern Africa Standby Brigade Coordination Mechanism (EASBRICOM) is more interesting. Ethiopia and Uganda have both paralleled Kenya's growth, and with Kenya's dip in 2012, Ethiopia is closing the gap. In the Economic Community of Central African States (ECCAS), Congo and Gabon are both well behind Cameroon, and showing only intermittent growth. In each of the four regions, even ECCAS, there is a clear leader in the production of new knowledge indicated by citable documents. ${ }^{59}$

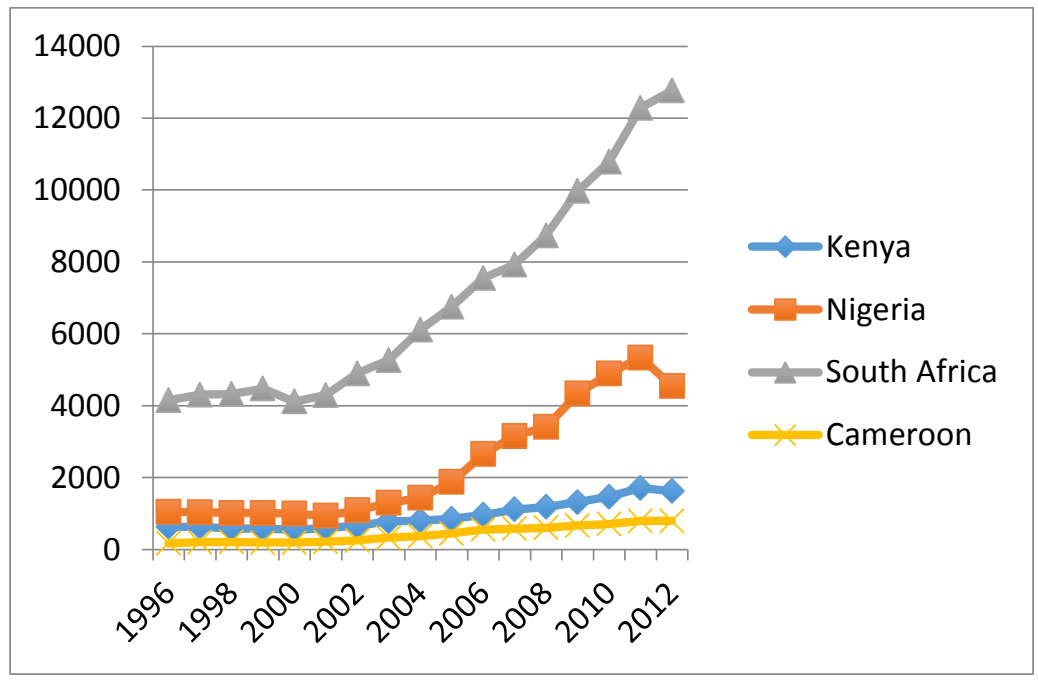

Figure 1: Citable documents (vertical axis) for regional leaders, 1996-2012

Size does not have to be the determining factor in intellectual leadership. Until 2000, Singapore had a clear lead in citable documents amongst Southeast 
Asian countries; Malaysia's concerted national policy focusing on education allowed it to surpass Singapore and continue to be the largest producer of citable documents in the region - well ahead of the largest country in the region, Indonesia. ${ }^{60}$ Size, wealth and effective governance mark today's hubs in Africa, but the Asian example demonstrates that small but well-governed countries like Botswana, Ghana and Senegal also have regional leadership potential.

\section{Education and regional security complexes}

Educational research has identified the strategy of establishing a regional hub to gain a competitive advantage in higher education and knowledge industries. ${ }^{61}$ This might be construed as a fad or branding exercise, but it is also true that collocation and cross-border interaction engender innovation and collaboration. ${ }^{62}$ Mid-career military staff colleges in countries with the greatest potential to act as regional hubs may be the best focal points for building regional security communities. This would not be true if the countries were focused on competitive pursuit of national interest at the expense of neighbouring states. However, our interviews have identified at least four mechanisms that shape the way in which security institutions might contribute to cooperative regional security. First, the African Peace and Security Architecture (APSA) provides career incentives for regional cooperation, and continental initiatives like the African Conference of Commandants (ACOC) reinforce them. Second, security innovation within regions seems to be collaborative rather than competitive. Third, regional training centres for peace support operations provide useful interchange on the superordinate goal of peace operations. Finally, pursuit of career objectives within a national context is helped by links to universities and think-tanks with international connections.

The APSA was established in 2002, and the African Union Peace and Security Department (AUPSD) commissioned an assessment report in 2010 under the leadership of Lieutenant General (retired) Louis Matshwenyego Fisher of Botswana. $^{63}$ The regional economic communities that make up the African Union (AU) form the framework for a continental early warning system. Regional brigades contribute to regional components of an African Standby Force (ASF), each element of which is assessed by international teams. ${ }^{64}$ Senior officers acknowledged that there is some reluctance to criticise; nevertheless, the pressure to meet international expectations has helped to raise professional standards. Staff colleges bear the brunt of preparing officers to meet these planning targets.

The SADC provides a framework for regional security cooperation in southern Africa, including five sectors within which mid-ranking to senior officers 
can find interesting and rewarding career opportunities. Regional security and defence coordination, state security, public security and cross-border police coordination together regularly engage hundreds of officers from each of the SADC countries. ${ }^{65}$ As these sectors evolve, there are opportunities for regional travel. Subcommittees and working groups meet regularly on defence intelligence, maritime coordination and anti-piracy, aviation, military health, chaplains' work, and logistics harmonisation for regional operations. Participants are almost always staff college graduates, and have often met each other on exchanges and regional exercises before they work together in committees. Staff colleges also serve as the main vehicles for organising regional exercises, and regularly host diplomatic and political figures from states in the region as part of the regional exercises. ${ }^{66}$

A common language enhances cooperation. The working language for international exchanges is almost universally English, except within la francophonie. Francophone officers in West Africa are expected to be bilingual. In east Africa, an innovation spurred by multinational peace operations is to encourage soldiers to communicate in Swahili or Kinyarwanda as a common 'soldiers' language' for the regional ASF. The language of instruction in almost all senior courses outside la francophonie is English, and operations orders and instructions are generally written in English, making regional cooperation easier. ${ }^{67}$

The 2012 meeting of the African Conference of Commandants (ACOC) addressed the role of staff colleges in preparing officers to meet emerging security challenges. ${ }^{68}$ After plenary presentations, four panels addressed emerging security challenges, the role of military education in meeting those challenges, strengthening professional development through cooperation, and curriculum harmonisation. The first panel identified the importance of good governance and leadership in managing emerging threats and the need for forward-looking studies and adjustments to available modules to meet the needs of specific countries. The panel on military education recommended more awareness of external environments, adaptability, and better decision-making, hinging on higher education. To improve professional development through cooperation, the third panel recommended broadening ACOC membership to higher and lower educational institutions, and expanding exchange programmes. Finally, the panel on harmonisation revealed some ambivalence. Although harmonisation and interoperability are written into the ACOC constitution (mirroring the language of NATO's Conference of Commandants), the discussion suggested members "evaluate/confirm the need for and interest in a harmonised curriculum". However, it also recognised "a need to develop a unified curriculum for an ASF response to operations other than war, and also to work on exercise scenarios as a way of enhancing and advancing harmonization efforts". ${ }^{69}$ The ACOC 
deliberations demonstrate the potential for regional cooperation building on midcareer staff colleges, particularly when focused on superordinate goals like peacekeeping and humanitarian operations.

This leads us to the second mechanism reinforcing regional security communities, namely collaborative innovation. Institutional development within the AU tends to reinforce regional communities because it requires military, police and diplomatic leaders to work together over time, and gives them incentives to do so. This is evident in the way that national institutions like staff colleges respond to regional processes like SADC policy development. Committee reports from the working level are brought to summits, which approve them for implementation. There is typically a two- to three-year cycle for new policies on issues like logistics standards, cross-border movement, or command and control for regional exercises. Action plans developed by staff in response to these policies are disseminated to SADC member states. Those affecting military forces are picked up by ministries of defence, and eventually flow down to staff colleges. Under the pressure of preparing for regional exercises, the cycle can be reduced to a single year, requiring a lot of communication at the working level. ${ }^{70}$

Innovation also involves universities with regional and international connections. Both national and regional staffs sometimes fund universities to address security-related questions, such as the effect of the 2008 financial crisis on regional security, but several participating officers expressed frustration that the results are often too academic to be useful (a familiar complaint on other continents as well). Cooperation with faculty at civilian universities seems to be increasing, with new initiatives by staff colleges and academies in Kenya, Ghana, Namibia, Tanzania and Botswana, and continuing collaborations in South Africa and Nigeria. ${ }^{71}$ Partnership with civilian universities to offer bachelor's degrees at the entry level or master's degrees at mid-career staff colleges is widespread in other parts of the world, and catching on in Africa. The South African Military Academy offers a BA degree through Stellenbosch, and the Defence Command and Staff College of Botswana offers an MA degree through the University of Botswana. Curriculum development with civilian universities is always a meeting of cultures, as universities insist on academic rigour, and staff colleges plead for professional relevance. Academic staff visits have helped to provide external benchmarks, and the ACOC has supported the process. ${ }^{72}$

Field experience is another source of collaborative innovation. The results of exercises and multinational operations accumulate as 'lessons learned' in regional centres and national headquarters, and are transmitted through instructors and individual participants in short courses, exercises or staff college courses. Few 
African countries have mature doctrine-development processes, so the most common vehicle for formalising these insights is presentations at staff colleges. ${ }^{73} \mathrm{~A}$ drawback is that the lifespan of an insight might be limited to the posting cycle of staff college instructors - two or three years.

Extra-continental influences can overshadow collaborative innovation within regions, but this may be changing. In police, gendarme as well as military training and education, there is still a lot of overseas influence: written materials, doctrine, vocabulary, organisations and processes are more likely to originate in Europe or North America than in Africa. Part of the explanation is technical. As long as equipment comes from abroad, manuals and technical instruction must also be imported. ${ }^{74}$ However, doctrine is different. Participating officers from major to general lamented the lack of reflection on indigenous experience: "we haven't learned from our own experiences yet", "There is no after action report on the Uganda-Tanzania war", "There is very little reflection on our own experiences." This has begun to change in the last four or five years, as staff college students are expected to write original and professionally relevant articles. Majors at the Botswana Defence College discussed writing articles on China's influence, the effect of the 2008 crash on African economic development, African states' role in peacekeeping, and foreign encroachment on maritime resources. As these studies accumulate in staff college libraries, they become the footnotes for future security thinking.

The third mechanism reinforcing regional security communities is the role of regional centres. Regional peace support training centres help to bring international learning into the regions, because UN and bilateral programmes support them with material and international instructors. They are inherently collaborative. Short courses of five to ten days often involve officers of 10 or more countries, who take comprehensive instruction packages back to national schools and staff colleges ${ }^{75}$ In turn, staff colleges contribute material to peace support training centres by sharing instructors and experienced retired officers. Because of this two-way traffic, regional centres are potential hotbeds of innovation, but do not always preserve material well, nor are they equipped to evaluate new knowledge, except through the experience of participants.

The strengths, but also the weaknesses, of centres relying on foreign funding are evident in an example. The Southern African Defence and Security Management Network (SADSEM) was established with the support of the Danish International Development Agency (DANIDA) to provide courses on civil-military relations, defence and security management, security sector governance, and managerial oversight of the security sector in collaboration with a network of police colleges 
and teaching institutions. When the funding stopped in 2008, there was no repository for the course material, thus no potential to continue the courses, even when local resources became available. $^{76}$

Lack of consistent funding also undermines the African Peace Support Trainers Association (APSTA). The number and quality of courses offered by centres are limited by international funding. The SADC Regional Peacekeeping Training Centre in Harare, for example, puts on only eight courses a year in Zimbabwe's current isolation, while the Nairobi Centre manages 22. The Nairobi centre and the Kofi Anan International Peacekeeping Training Centre (KAIPTC) in Ghana are part of an international network, but other African centres are not. ${ }^{77}$ Because the centres run short courses in a variety of locations, they tend not to be repositories of knowledge. They have no substantial libraries, do not collect data regularly, nor do they make consistent research contributions, although several have periodical or occasional publications. KAIPTC is an exception, offering master's degrees in Conflict, Peace and Security, and in Gender, Peace and Security in cooperation with the Ghana Institute of Management and Public Administration. ${ }^{78}$

The experience of regional centres and short courses reinforces the argument that broadening the role and engagement of mid-career staff colleges might be a more effective way of enhancing regional security complexes. Co-locating peace support training centres with staff colleges would be an obvious step in this direction.

The fourth mechanism enhancing regional security communities is the pursuit of career advantage by senior officers. Regional centres contribute material to staff colleges, which helps to internationalise colleges' outlook and perspective on regional problems. As officers advance, they seek career opportunities in security beyond retirement, often in universities and think-tanks with an international perspective. Privately funded think-tanks like Chatham House, the Royal United Services Institute (RUSI), or Foreign Policy, have few analogues in Africa, but there is a demand for them by senior leaders seeking employment, who find the constraints of publicly funded universities too limiting. ${ }^{79}$ The Institute for Security Studies (ISS) is based in South Africa, but now has offices in Nairobi, Dakar and Addis Ababa as well as Pretoria and Cape Town.

Foreign funding for think-tanks and institutes of strategic studies with a policy focus might support regional integration, but it might also support strategic competition. The problem is that more funds and prestige may be available from connections with Washington or Beijing than from connections with Dodoma or Windhoek, and this might shape thinking on regional security issues. The prospects 
for regional security communities are affected by national and inter-regional dynamics, and by the overlay and penetration of African security complexes by multilateral and bilateral influences. Some of these influences may emerge as barriers to regional human security communities.

\section{Conclusions}

Drawing on a larger global study, we have summarised general patterns of police, gendarme and military education in sub-Saharan Africa, and suggested the prospects for regional collaboration around potential hubs for security education.

Investing in mid-career staff colleges and the critical thinking skills of higher education might help to support the emergence of communities of security professionals in the service of regional security communities. Linking regional centres, civilian universities and research programmes to institutions for higher professional education might create the new knowledge necessary to address emerging security challenges. That knowledge can be generated within African institutions, rather than in foreign centres remote from African realities.

We have not explored the content and influence of security education in Africa. That remains a goal for the Global Security Education Project. Who is learning what? Are security leaders only learning to fight wars and suppress domestic threats, or are they learning to manage security and prevent violence? Does it matter, in the end, what they learn if they are only tools of civilian leaders or prisoners of a strategic dilemma? Can we educate professional managers of violence to construct collaborative solutions to the security dilemmas of the future? That is the challenge facing today's educators, in Africa, as on other continents.

\section{Endnotes}

${ }^{1}$ Moyo, D. Dead aid: Why aid is not working and how there is a better way for Africa. New York: Farrer, Straus and Giroux, 2009.

${ }^{2}$ To label them habitual coup leaders is an unfair generalisation. See Gibler, DM \& Ruby, TZ. "Educating foreign officers". Joint Forces Quarterly Winter 2003. 119-123. 〈http://www.dtic.mil/dtic/tr/fulltext/u2/a483696.pdf> Accessed 4 May 2015.

${ }^{3}$ MacGinty, R \& Williams, A. Conflict and development. London: Routledge, 2009, Chapter 1.

${ }^{4}$ See Aradau, C, Huysmans, J, Neal, A \& Voelkner, N (eds). Critical security methods: New frameworks for analysis. London: Routledge, 2015, Chapter 1 , for a description of security praxis as method. 
${ }^{5}$ Majority states are those below the top tier of the large and powerful - the P5, and those with populations over 200 million - and above the bottom tier of microstates.

${ }^{6}$ This is implied by the usual usage, "adapting behaviour to the norms of a culture or society”: Lawson, T \& Garrod, J (eds). Dictionary of sociology. London: Fitzroy Dearborn, 2001.

${ }^{7}$ This distinction is taken from Kratcoski, PC \& Das, DK (eds). Police education and training in a global society. Lanham, CT: Lexington Books, 2007, Chapter 1: "Definitions of education and training".

${ }^{8}$ Caforio, G. "Military officer education". In Caforio, G (ed), The handbook of the sociology of the military, New York: Springer, 2006, 255.

${ }^{9}$ The Magna Charta Universitatum of 1988 is the starting point for university principles (http://www.magnacharta.org/library/userfiles/file/mc_english.pdf) and the Bologna process for the Harmonization of the European Higher Education Area based on the Bologna Declaration of 1999 (http://www.ehea.info/Uploads/Declarations/BOLOGNA_DECLARATION 1.pdf).

${ }^{10}$ National embassies in Ottawa and Washington were contacted for institutional points of contact. Six of 37 embassies responded, and no additional information came from the contacts provided. African researchers engaged in security research in Uganda, Tanzania and Nigeria were contacted through the Commonwealth Scholars Network supported by the British Council. One of these collaborators provided some institutional details. Canadian Defence Attachés helped arrange interviews in several countries.

${ }^{11}$ Countries: Benin, Botswana, Canada, Chad, Djibouti, Egypt, Jordan, Kenya, Mali, Namibia, Rwanda, Senegal, Sierra Leone, South Africa, Tanzania, Uganda, Zimbabwe. Institutions: African Conference of Commandants (secretariat), AMISOM Staff, Botswana Defence College, Ecole Interarmes Koulikoro, IPSTC Kenya, KAIPTC Ghana, Nigerian National Defence Academy, Paje Officer Academy Botswana, PSTC Bamako, SADC Gaborone Office, South African Defence College, South African Defence Academy Saldanha Bay, South African War College, UN DPKO, University of Botswana, Stellenbosch University.

${ }^{12}$ Global Security Education Project collaborative research space (www.othree.ca/globalsecurity). This site is password-protected, but open to those teaching and researching in higher education institutions for security forces. 
${ }^{13}$ Sweeney, L. “Achieving k-anonymity privacy protection using generalization and suppression". International Journal of Uncertainty, Fuzziness and Knowledge-Based Systems 10/5. 2002. 571-588.

${ }^{14}$ Wendt, A. "Constructing international politics". International Security 1995 (Vol. 20, No. 1. Summer, 1995) 71-81.

${ }^{15}$ Pinker, S. The better angels of our nature: Why violence has declined. New York: Viking, 2011; Tilly, C. The politics of collective violence. Cambridge: Cambridge University Press, 2003.

${ }^{16}$ Rummel, R. Death by government. New York: Transaction Press, 1997.

${ }^{17}$ Goldstein, J. Winning the war on war: The decline of armed conflict worldwide. New York: Penguin, 2011.

${ }^{18}$ See, for example, Bayley, D. "International differences in community policing". In Rosenbaum, D. P. (ed), The challenge of community policing: Testing the promises, Thousand Oaks, CA: Sage, 1994, 278-81; Gregory, S. "The French military in Africa: Past and present”. African Affairs 99/396. 2000. 435-448; Visser, D. "Neither Sandhurst nor West Point: The South African Military Academy and its foreign role models". Historia 46/2. 2001. 387.

19 This generalisation is drawn from a survey of 193 countries, in which 545 security education institutions have been identified. Additional data have been compiled since this was reported in 2011. Last, D, Emelifeonwu, D \& Langlois, M. "Separate worlds: A comparison of police and military education with deductions about common curriculum and education assistance". Paper presented to the Working Group on Blurring of Police and Military Roles, 11th Biennial Conference of ERGOMAS, Amsterdam, 1317 June 2011.

${ }^{20}$ Last, D. "How high is the bar and where's the beef? Military degrees". Canadian Military Journal Summer 2004 (Issue 5, No. 2). Educational research has explored concepts of competency and higher education in greater detail. See, for example, Barth, M, Godemann, J, Rieckmann, M \& Stoltenberg, U. "Developing key competencies for sustainable development in higher education". International Journal of Sustainability in Higher Education 8/4. 2007. 416-430.

21

European University Association, "Bologna - an overview of the main elements," EUA Work and Policy Area: Building the European Higher Education Area, Brussels: EUA web site, http://www.eua.be/eua-workand-policy-area/building-the-european-higher-education-area/bolognabasics/Bologna-an-overview-of-the-main-elements.aspx accessed 5 May 2015. 
${ }^{22}$ The more vigorously we apply the Bologna criteria, the lower the percentage. Autonomy, truth seeking and independent faculty research agendas are difficult for many military and police educational institutions. Data by region are available from the authors or online at http://www.davidmlast.net/ARP_Research/Design.html and in forthcoming publications.

${ }^{23}$ Buzan, B \& Waever, O. Regions and powers: The structure of international security. Cambridge: Cambridge University Press, 2003, Part III.

${ }^{24}$ See, for example, Association of American Medical Colleges and Liaison Committee on Medical Education. Functions and structure of a medical school: Standards for accreditation of medical education programs leading to the MD degree. Washington, DC: Liaison Committee on Medical Education, 2003.

${ }^{25}$ Last, D. "Irritants to pearls: Military education, epistemic communities, communities of practice and networks of learning". Proceedings of the International Society of Military Sciences Annual Conference, 2014 (forthcoming).

${ }^{26}$ In the Anglosphere, all police are often referred to as 'officers', so we have used the term 'police leadership' to refer to command positions such as inspectors, superintendents and commissioners.

${ }^{27}$ Oyakhilome, F, Alemika, EO \& Abati, R. Police Service Commission Retreat on understanding the mandate and operations of the PSC in the context of the rule of law. Abuja, 2008, Table 1; Ahanotu, OC. "Fostering transformative curriculum in the Nigerian Police Force: A new perspective for the $21^{\text {st }}$ century". PhD dissertation. Capella University, 2006. The small number of respondents with degrees were mainly in English, history, political science and education, with none in police science, law or criminal justice.

${ }^{28}$ Kurian, G (ed). World Encyclopedia of Police Forces and Correctional Systems ( $2^{\text {nd }}$ ed). Detroit, MI: Gale, 2006.

${ }^{29}$ Alary, E. L'Histoire de la Gendarmerie. De la Renaissance au troisième millénaire. Paris: Calmann-Lévy, 2000.

${ }^{30}$ The Cours d'applications des officiers de gendarmerie (CAOG) in Ouakam, Senegal, offers about 50 places a year to African officers. One-third of the places are for Senegal. Ministère des Affaires étrangères et européenne. "Les écoles nationales à vocation régionale". Direction de la coopération de sécurité et de défense, Paris. <http://www.diplomatie.gouv.fr/fr/IMG/pdf/Depliant ENVR complet.pdf> Accessed 4 May 2015. 
${ }^{31}$ Levine, DH. African civilian police capacity for international peacekeeping operations. Washington, DC: Henry L. Stimson Center, 2008.

${ }^{32}$ Studies of military education usually focus on the Western experience. Some examples: Van Creveld, M. The training of officers: From military professionalism to irrelevance. New York: Free Press, 1990; Janowitz, M \& Wesbrook, SD. Political education of soldiers. London: Sage, 1983;

Masland, JW \& Radway, LI. Soldiers and scholars: Military education and national policy. Princeton, NJ: Princeton University Press, 1957. See our other work for more extensive bibliographies.

${ }^{33}$ See the alumni lists on the website of the National Defence College of Kenya (http://www.ndc.go.ke/Alumni.php) or the South African National Defence College entrance requirements (http://www.defcol.mil.za), or the admission policy of the National Defence College of Nigeria (http://www.ndc.gov.ng/index.php/about/admission-policy).

${ }^{34}$ Interviews, Gaborone, 2011.

${ }^{35}$ Interviews, Gaborone, 2011; Sentul, 2014.

${ }^{36}$ Nigerian Defence Academy. "Postgraduate history". <http://www.nda.edu.ng/content.php?pid=2056> Accessed 4 May 2015, and interviews with faculty.

${ }^{37}$ South African Defence Force. "Military Academy introduction". <http://sadf.info/Military\%20Academy\%20Introduction.html > Accessed 4 May 2015, and interviews with faculty.

${ }^{38}$ Kenia Military Academy. "Brief history about KMA". <http://kma.mod.go.ke/index.php/2014-07-20-03-51-59/brief-history>

Accessed 4 May 2015, plus interviews.

${ }^{39}$ Kenyatta University. "Programmes".

<http://www.ku.ac.ke/ipss/index.php/programmes> Accessed 4 May 2015, and interviews

${ }^{40}$ This was evident in interviews with officers from Botswana, Ghana and Namibia conducted in 2011.

${ }^{41}$ Thomas, G. Education: A very short introduction. Oxford: Oxford University Press, 2013. In Chapter 6, "The curriculum", Thomas explains that curriculum includes content, but also methods of instruction and evaluation, and the processes by which curriculum evolves.

${ }^{42}$ Interviews and open source database, available at <www.othree.ca/globalsecurity> Accessed 4 May 2015.

${ }^{43}$ Potgeiter, J \& Ndungu, I. "The role of staff colleges in preparing officers to meet emerging security challenges". Report of the $6^{\text {th }}$ African Conference of 
Commandants, Abuja, 5-7 November 2012. Pretoria: Institute for Security Studies. 〈http://www.acoc-africa.org/docs/6thACoCConferenceReport.pdf> Accessed 4 May 2015.

${ }^{44}$ Grey literature consists of "non-conventional, fugitive, and sometimes ephemeral publications. They may include, but are not limited to the following types of materials: reports (pre-prints, preliminary progress and advanced reports, technical reports, statistical reports, memoranda, state-of-the art reports, market research reports, etc.), theses, conference proceedings, technical specifications and standards, non-commercial translations, bibliographies, technical and commercial documentation, and official documents not published commercially (primarily government reports and documents)" (The New York Academy of Medicine. "What is grey literature?" Grey Literature Report. 〈http://www.greylit.org/about> Accessed on 4 May 2015.

45 Alberani, V, De Castro Pietrangeli, P. \& Mazza, A.M. "The use of grey literature in health sciences: A preliminary survey". Bulletin of the Medical Library Association 78/4. 1990. 358. Correspondence with staff college librarians suggests the rising importance of grey literature.

${ }^{46}$ Interviews, Gaborone, December 2011.

${ }^{47}$ This information is from course participants at several international training events, who were vague about the precise names of the courses involved. Canadian and foreign defence attachés have confirmed the existence of such courses, but not the details.

${ }^{48}$ Interviews with defence attachés.

${ }^{49}$ Interview with one former participant. See also NDC websites cited above, note 32. Tanzania established a National Defence College in 2012 (www.ndctz.go.tz).

${ }^{50}$ Based on global data available at $\langle\underline{w w w}$.othree.ca/globalsecurity $>$ Accessed on 4 May 2015.

${ }^{51}$ One respondent referred to National Defence College as a "consolation prize". Another expressed the view that those destined for the highest command positions would not take a year out of the country to attend a foreign course.

${ }^{52}$ A retired general officer explained the importance of his national defence college course to help him establish a strategic think tank.

53 This is a fast-moving target, and the numbers are increasing through partnerships with civilian universities and efforts to accredit or legislate degree-granting authority in many countries around the world.

${ }^{54}$ Cline was one of the analysts to popularise use of GDP as part of a calculus of power. Cline, RS. World power trends and US foreign policy for the 1980s. 
Vol 80. Boulder, CO: Westview Press, 1980. Population as an indicator can be improved by considering literacy or education, but that is not necessary here. GDP has its detractors (Fioramonte, 2013) but also advantages (Coyle, 2014). Fioramonti, L. Gross Domestic Problem: The politics behind the world's most powerful number. New York: Zed Books, 2013; Coyle, D. GDP: A brief but affectionate history. Princeton, NJ: Princeton University Press, 2014.

55 SCImago Country and Journal Rank. "The Shape of Science". <www.scimagojr.com> Accessed on 4 May 2015.

${ }^{56}$ A discussion paper on use of the indicator is available at <www.othree.ca/globalsecurity> Accessed on 4 May 2015

${ }^{57}$ Completion of BA is a prerequisite for entry to Paje Officer Academy since 2009. The Kenyan Military Academy at Nakuru made arrangements with Jomo Kenyatta University for officer education in 2010.

${ }^{58}$ Compiled by authors from open sources and interviews. Population (millions) and GDP (billions of USD), World Bank, 2012. Citable documents (thousands) from SCImago Journal and Country Rankings, cumulative 1996-2012. Freedom House (2012) for Column Z.

${ }^{59}$ Figures drawn from SCImago, compiled and analysed with the assistance of Luis Flores.

${ }^{60}$ David Last, "Security Education in Malaysia," Sabbatical Work and Reports, Kingston, ON: http://www.davidmlast.net/Sabbatical/Revised.html, p.3.

${ }^{61}$ Knight, J. "Education hubs: A fad, a brand, an innovation?” Journal of Studies in International Education 15/3. 2011. 221-240

${ }^{62}$ Ibid. and Knight, J \& Morshidi, S. "The complexities and challenges of regional education hubs: Focus on Malaysia”. Higher Education 62/5. 2011. 593606.

${ }^{63}$ African Union. "Moving Africa forward: African Peace and Security Architecture (APSA) 2010 Assessment Study". November 2010. <http://www.securitycouncilreport.org/atf/cf/\%7B65BFCF9B-6D27-4E9C8CD3-

CF6E4FF96FF9\%7D/RO\%20African\%20Peace\%20and\%20Security\%20Ar chitecture.pdf $>$ Accessed on 4 May 2015.

${ }^{64}$ Ibid., p. 40.

${ }^{65}$ SADC Secretariat. "Politics, defense and security". <http://www.sadc.int/sadcsecretariat/directorates/office-executive-secretary/organ-politics-defenseand-security/> Accessed on 4 May 2015, and interviews, Gaborone, December 2011.

${ }^{66}$ Interviews, Gaborone, December 2011. 
${ }^{67}$ Interviews, Gaborone, December 2011; Sentul, January 2014.

${ }^{68}$ Potgeiter \& Ndungu op. cit. and the record of decisions at the $6^{\text {th }}$ African Conference of Commandants. "Decisions of the $6^{\text {th }}$ African Conference of Commandants". Abuja. $<$ http://www.acocafrica.org/docs/6thACoCDecisions.pdf $>$ Accessed on 4 May 2015, p. 8.

${ }^{69}$ Ibid., p. 8.

${ }^{70}$ Interviews with SADC staff, Gaborone, December 2011.

${ }^{71}$ Interviews and correspondence.

${ }^{72}$ Two of the authors have been involved in these visits and ongoing discussions.

${ }^{73}$ Interviews.

${ }^{74}$ This explanation came from an American technical team in Botswana, and was corroborated by Nigerian and Tanzanian officers in 2011 .

${ }^{75}$ Interviews with instructors and students from the International Peace Support Training Centre, Nairobi, Kenya, and the Kofi Annan International Peacekeeping Training Centre, Accra, Ghana, in 2010 and 2011.

${ }^{76}$ Interviews, University of Botswana, December 2011.

${ }^{77}$ The Certificate of United Nations Peace Support Operations (COTIPSO) is offered through the Peace Operations Training Institute (POTI), a non-profit organisation based in Williamsburg, VA.

${ }^{78}$ KAIPTC website: www.kaiptc.org

${ }^{79}$ This was a complaint by two general officers, recently retired in different countries. Although a small sample, we have heard similar complaints in other settings (Brazil and Indonesia). 